\title{
Optimization of production, purification and lyophilisation of cellobiose dehydrogenase by Sclerotium rolfsii
}

\author{
Christin Fischer ${ }^{*}$, Annett Krause and Thomas Kleinschmidt
}

\begin{abstract}
Background: The enzyme cellobiose dehydrogenase $(\mathrm{CDH})$ can be used to oxidize lactose to lactobionic acid. As Sclerotium rolfsii is known to be a good producer of $\mathrm{CDH}$, the aim of this paper was to simplify its production and secondly to systematically study its purification aiming for a high yield. Two preservation methods (freezing and freeze-drying) and the influence of several protectants were investigated.
\end{abstract}

Results: Production of cellobiose dehydrogenase was optimized leading to a more simplified medium composition. Purification of the enzyme was evaluated by determining breakthrough profiles on different ion exchange (IEX) and hydrophobic interaction (HIC) materials with regard to buffer composition. Highest purification with an acceptable loss during the capture step using IEX was obtained with a Q Sepharose XL medium and a $100 \mathrm{mM}$ sodium acetate buffer at pH 4.5. Subsequent purification using hydrophobic interaction chromatography was done at $1.1 \mathrm{M}$ ammonium sulfate concentration. Purification was moderate, yielding a specific activity of $11.9 \mathrm{U} / \mathrm{mg}$ (56\% yield). However, as could be shown in a preliminary experiment, purity of the obtained enzyme solution was sufficient for its intended use to oxidize lactose to lactobionic acid. Various sugars and sugar alcohols were investigated to study their protective effect during lyophilisation and freezing at $-20^{\circ} \mathrm{C}$. Glucose and lactulose could be identified to have a high lyoprotective effect while loss of enzyme activity was high (77\%) when using no additives.

Conclusion: By simplifying the cultivation medium of Sclerotium rolfsii, the costs of cellobiose dehydrogenase production could be reduced. Simultaneously, CDH production was increased by $21 \%$. The production of lactobionic acid from lactose is possible using partially purified and unpurified enzyme. Storage at $-20^{\circ} \mathrm{C}$ using $50 \%$ $(w / v)$ glycerol was considered to be most suited for preservation of the enzyme.

Keywords: Cellobiose dehydrogenase, $\mathrm{CDH}$, Sclerotium rolfsii, Enzyme purification, Lyophilisation, Cryoprotection, Lactobionic acid

\section{Background}

Cellobiose dehydrogenase (CDH, EC 1.1.99.18) is an extracellular enzyme produced by a number of wooddegrading fungi [1]. One of them is the plant pathogen Sclerotium (Athelia) rolfsii which is common in the tropics and subtropics and attacks mostly crops and vegetables. It is mainly producing cellulolytic enzymes in order to enter the host organism [2]. The biological function of $\mathrm{CDH}$ is controversial. For example, $\mathrm{CDH}$ increases the efficiency of cellulose degradation or reduces

\footnotetext{
* Correspondence: c.fischer@bwp.hs-anhalt.de

Anhalt University of Applied Sciences, Department of Applied Biosciences and Process Engineering, Bernburger Str. 55, 06366 Köthen, Germany
}

product inhibition of cellulases by oxidizing cellobiose to the corresponding lactone $[1,3]$. This theory was also confirmed several years later [4].

$\mathrm{CDH}$ is a monomeric protein consisting of a flavin and a heme domain. Both domains are connected by a protease-sensitive linker. When $\mathrm{CDH}$ is cleaved by proteases, it results in an active flavin domain and an inactive heme fragment. It is possible to distinguish between the holoenzyme and the flavin domain by using both one and two electron acceptors. Two electron acceptors like 2,6-dichlorophenol-indophenol (DCIP) can be reduced either directly at the flavin domain or via internal electron transfer at the heme domain. One electron acceptors 
like cytochrome c can only be used at the heme domain. Thus, they are used to detect only the intact enzyme.

As indicated by its name, cellobiose is the main substrate of the enzyme [5-9] indicated by a low Michaelis Menten constant. Other cellooligosaccharides are also favoured [10] but another common substrate is lactose. Figure 1 shows the reaction mechanism using DCIP as a redox mediator. The corresponding lactone is spontaneously oxidized to lactobionic acid which is rumored to have prebiotic effects [11]. Thus, an application in the food industry is a possible alternative to its current usage in biosensors for glucose $([12,13])$ or lactose ([14-16]) and as a bleaching agent ([17-19]).

As Sclerotium rolfsii is known to be a good producer of $\mathrm{CDH}$, the aim of this paper was to simplify its production and secondly to systematically study its purification aiming for a high yield. Two preservation methods (freezing and freeze-drying) and the influence of several protectants were investigated.

\section{Methods}

\section{Organism and culture conditions}

Sclerotium rolfsii strain CBS 191.62 was obtained from the Centraalbureau voor Schimmelcultures (Baarn, The Netherlands). The fungus was maintained on glucosemaltose Sabouraud agar plates, which were inoculated with a piece (diameter $1 \mathrm{~cm}$ ) of overgrown agar and then incubated at $30^{\circ} \mathrm{C}$ for 5 to 7 days.

A medium propagated by Sachslehner et al. [2] was used in some studies. It contained $43 \mathrm{~g} / \mathrm{L} \alpha$-Cellulose,

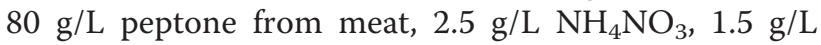
$\mathrm{MgSO}_{4} \times 7 \mathrm{H}_{2} \mathrm{O}, 1.2 \mathrm{~g} / \mathrm{L} \mathrm{KH}_{2} \mathrm{PO}_{4}, 0.6 \mathrm{~g} / \mathrm{L} \mathrm{KCl}$, and 0.3 $\mathrm{ml} / \mathrm{L}$ trace element solution $\left(1.0 \mathrm{~g} / \mathrm{L} \mathrm{ZnSO}_{4} \times \mathrm{H}_{2} \mathrm{O}, 0.3\right.$ $\mathrm{g} / \mathrm{L} \mathrm{MnCl}_{2} \times 4 \mathrm{H}_{2} \mathrm{O}, 3.0 \mathrm{~g} / \mathrm{L}_{3} \mathrm{BO}_{3}, 2.0 \mathrm{~g} / \mathrm{L} \mathrm{CoCl}_{2} \times$ $6 \mathrm{H}_{2} \mathrm{O}, 0.1 \mathrm{~g} / \mathrm{L} \mathrm{CuSO}_{4} \times 5 \mathrm{H}_{2} \mathrm{O}, 0.2 \mathrm{~g} / \mathrm{L} \mathrm{NiCl}_{2} \times 6 \mathrm{H}_{2} \mathrm{O}$ and $4.0 \mathrm{ml} / \mathrm{L}$ conc. $\mathrm{H}_{2} \mathrm{SO}_{4}$ ). The natural $\mathrm{pH}$ of the medium was 5.5. For optimizing the culture conditions of Sclerotium rolfsii with regard to maximum production of cellobiose dehydrogenase, start $\mathrm{pH}$ was varied (5.5, 5.0 and 4.0) by adding appropriate amounts of phosphoric acid. Additionally, a pH-stat method for a start $\mathrm{pH}$ value of 5.5 was carried out by measuring and readjusting the $\mathrm{pH}$ to 5.5 with $5 \mathrm{M} \mathrm{NaOH}$ on a daily basis.

Further, the composition of the medium was modified. The medium of Sachslehner et al. [2] was used as a reference. First, single salts were omitted from the medium described above to evaluate their influence on enzyme production. In a second series, a basal medium containing $43 \mathrm{~g} / \mathrm{L} \alpha$-Cellulose, $80 \mathrm{~g} / \mathrm{L}$ peptone from meat and $0.3 \mathrm{ml} / \mathrm{L}$ trace element solution was used. $\mathrm{NH}_{4} \mathrm{NO}_{3}$, $\mathrm{MgSO}_{4}, \mathrm{KH}_{2} \mathrm{PO}_{4}, \mathrm{KCl}$ or none of them were added (amounts as in the reference medium).

All experiments were carried out in $300 \mathrm{ml}$ unbaffled Erlenmeyer flasks containing $100 \mathrm{ml}$ culture medium. Flasks were inoculated with 2 agar plugs (diameter 1 $\mathrm{cm}$ ) of a freshly grown culture and incubated at $30^{\circ} \mathrm{C}$ and $150 \mathrm{rpm}$ until enzyme activity remained constant. Samples of $1 \mathrm{ml}$ were withdrawn starting after 7 days of incubation and analyzed for enzyme activity.

\section{Enzyme purification}

First, the mycelia were separated from the cultivation medium containing the $\mathrm{CDH}$ enzyme by filtration using a folded filter. This crude enzyme extract was desalted and concentrated to about one fifth of its initial volume using a Vivacell 250 filtration device (Sartorius AG, Germany) equipped with a PES membrane having a MWCO of $50 \mathrm{kDa}$. Within two dialysis steps and applying a pressure of 4 bar, conductivity was reduced from about $18 \mathrm{mS} / \mathrm{cm}$ to about $1 \mathrm{mS} / \mathrm{cm}$ indicating a successful salt removal. No enzyme loss was detected during this step.

Enzyme purification was carried out on an ÄKTA Prime Plus system (GE Healthcare) equipped with a 150 $\mathrm{ml}$ superloop for the application of large sample volumes. Different adsorbents for anion exchange (DEAE Sepharose FF as a weak and Q Sepharose XL as a strong ion exchanger, column volume: $5 \mathrm{ml}$, both by GE Healthcare) and hydrophobic interaction chromatography (Butyl-S FF, Butyl FF, Octyl FF, Phenyl HP, Phenyl FF (low sub), column volume: $1 \mathrm{ml}$, all by GE Healthcare) were tested to optimize purification procedure. With IEX, binding capacity was determined at

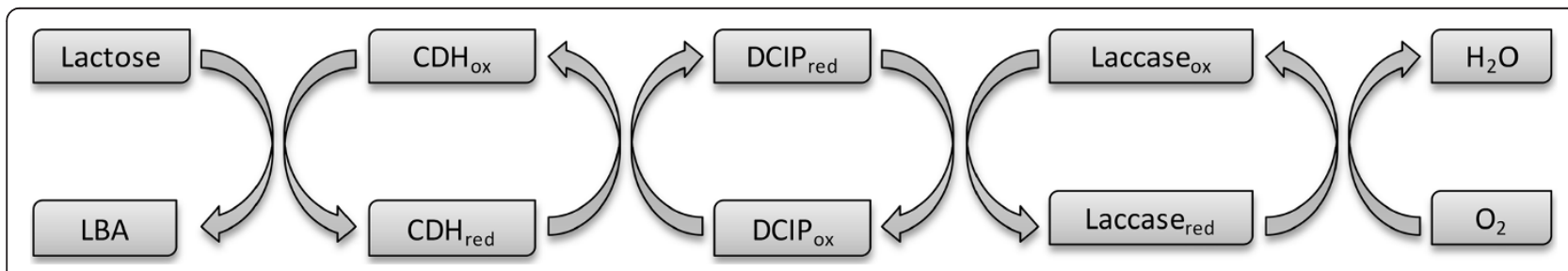

Figure 1 Reaction scheme of enzymatic oxidation of lactose to lactobionic acid (LBA). The used enzyme system consists of cellobiose dehydrogenase $(\mathrm{CDH})$ and laccase with 2,6-dichlorophenol-indophenol (DCIP) as redox mediator. 
various $\mathrm{pH}$ values (50 $\mathrm{mM}$ sodium acetate buffer) and buffer concentrations $(20-200 \mathrm{mM}$ sodium acetate, $\mathrm{pH} 4.5$ ) by applying $110 \mathrm{ml}$ of desalted and appropriately diluted crude enzyme extract (final concentration about $3 \mathrm{U} / \mathrm{ml}$ ) onto the column. Fractions $(2 \mathrm{ml})$ of the flow-through were collected and analyzed for $\mathrm{CDH}$ activity to determine a breakthrough profile. Also, elution conditions were optimized by analyzing the collected fractions for enzyme activity and protein content. Fractions having a higher specific activity than the applied sample were pooled. Ammonium sulfate precipitation was carried out by adding an appropriate amount of a 3.8 $\mathrm{M}$ solution to obtain the desired saturation before applying the sample to various HIC columns. Concentration and composition of the starting buffer were optimized as well.

\section{Preservation of the enzyme}

Seven sugars and two sugar alcohols were tested for their ability to serve as lyo- or cryoprotectants for CDH. Therefore $1 \mathrm{ml}$ of purified enzyme solution (containing $11 \mathrm{U} / \mathrm{ml}$ ) and $0.5 \mathrm{ml}$ of lyoprotectant solution (to give a final concentration of $10 \mu \mathrm{mol}$ per unit $\mathrm{CDH}$ ) were mixed and either frozen at $-20^{\circ} \mathrm{C}$ or freeze dried in $1.5 \mathrm{ml}$ Eppendorf tubes. Freeze-drying was carried out in an Alpha 1-4 freeze-dryer (Martin Christ Gefriertrocknungsanlagen $\mathrm{GmbH}$, Germany). Plate temperature was set to $-50^{\circ} \mathrm{C}$ and within 3 hours a product temperature of $-28^{\circ} \mathrm{C}$ was obtained. Vacuum (0.005 mbar) was applied and plate temperature was set to $30^{\circ} \mathrm{C}$. The process was stopped after 4 to 5 days when product temperature was positive. Samples were rehydrated with $1 \mathrm{ml}$ water immediately after drying and analyzed for residual enzyme activity. Frozen samples were thawed after 60 and 160 hours and also assayed for remaining $\mathrm{CDH}$ activity.

\section{Enzyme activity assay}

For measuring the enzyme concentration, the DCIP assay as propagated by Baminger et al. [20] was used. Therefore, $100 \mu \mathrm{l} 300 \mathrm{mM}$ lactose, $20 \mu \mathrm{l} 200 \mathrm{mM}$ NaF and $760 \mu \mathrm{l} 100 \mathrm{mM}$ sodium acetate buffer $\mathrm{pH} 4.0$ were incubated at $30^{\circ} \mathrm{C}$ for at least 10 minutes before analysis. A solution of $3 \mathrm{mM}$ DCIP (containing 10\% v/v ethanol) was tempered separately. For analysis, $100 \mu \mathrm{l}$ of DCIP solution were added to the lactose/ $\mathrm{NaF} /$ buffer mixture and $20 \mu$ l appropriately diluted sample solution was added. After mixing the reduction of DCIP was measured at 520 $\mathrm{nm}$ every 5 seconds for 3 minutes. The extinction coefficient for DCIP at $520 \mathrm{~nm}$ and $\mathrm{pH} 4.0$ was determined to be $6.9 \mathrm{mM}^{-1} \mathrm{~cm}^{-1}$. One unit was defined as the amount of enzyme that reduces $1 \mu \mathrm{mol}$ DCIP per minute under the described assay conditions.

\section{Protein determination}

Protein content was determined according to the Bradford method [21]. Therefore $100 \mu \mathrm{l}$ appropriately diluted sample solution were mixed with $1 \mathrm{ml}$ of Bradford reagent (Roti ${ }^{\circledR}$-Quant, Carl Roth $\mathrm{GmbH}$, Germany) and incubated for 10 minutes at room temperature. Extinction was measured at $595 \mathrm{~nm}$. Bovine serum albumin was used as a standard.

\section{Application of $\mathrm{CDH}$ for lactobionic acid synthesis}

The partial purified enzyme as well as the crude enzyme extract were used in a $4.8 \%$ lactose solution to synthesise lactobionic acid. Enzyme substrate ratio was set to 70 DCIP-Units per gram lactose. DCIP $(1 \mu \mathrm{mol} /$ unit CDH $)$ was used as a redox mediator and laccase from Trametes versicolor (Sigma Aldrich, Germany) was added in a 5fold excess over $\mathrm{CDH}$ activity. Reaction was carried out in a water bath at $35^{\circ} \mathrm{C}$ and $200 \mathrm{rpm}$. Samples were analyzed for glucose, galactose, lactose and lactobionic acid using HPLC. The column was a Hi-Plex Na column (300 mm x $7.7 \mathrm{~mm}$ from Agilent Technologies Deutschland $\mathrm{GmbH}$ ) which was used at $0.3 \mathrm{mLmin}^{-1}$ (eluent $0.2 \%$ sodium azide in water) and $80^{\circ} \mathrm{C}$.

\section{Results and discussion}

\section{Influence of culture conditions on $\mathrm{CDH}$ yield}

\section{Influence of $\mathrm{pH}$}

Figure 2 shows the influence of the starting $\mathrm{pH}$ of the medium. At $\mathrm{pH}$ 5.0 $\mathrm{CDH}$ production begins noticeably at day 10 , continues to rise straight and reaches a value of $7.3 \mathrm{U} / \mathrm{ml}$ after 17 days. With a slightly higher $\mathrm{pH}$ of 5.5 $\mathrm{CDH}$ production started a little earlier (day 7) and was significantly higher until day 10 . Thenceforward the measured enzyme activity was a little higher compared to a starting $\mathrm{pH}$ of 5.0 but that difference was not significant. Also, after 17 days the produced enzyme amount was the same as with $\mathrm{pH}$ 5.0. Although cultivation at a starting $\mathrm{pH}$ of 5.5 seemed to be a little instable (as indicated by high standard deviations), this value was used for further studies as 5.5 is the natural $\mathrm{pH}$ of the medium and therefore no adjustment is necessary. There was only very little $(0.1 \mathrm{U} / \mathrm{ml}) \mathrm{CDH}$ production at a $\mathrm{pH}$ of 4.0 (data not shown). Therefore this $\mathrm{pH}$ is not suitable.

Since the $\mathrm{pH}$ of the culture medium shifts to lower levels during cultivation, it was assumed using a $\mathrm{pH}$ stat method to cultivate at a constant $\mathrm{pH}$ value of 5.5 might further enhance $\mathrm{CDH}$ production. Therefore, an appropriate amount of $5 \mathrm{M} \mathrm{NaOH}$ was added on a daily basis. However, a maximum enzyme concentration of only $2.6 \mathrm{U} / \mathrm{ml}$ was reached after 13 days. It then slightly dropped down to $2.3 \mathrm{U} / \mathrm{ml}$ and remained on that level until the end of the experiment after 21 days. $\mathrm{CDH}$ production using cultivation without $\mathrm{pH}$ adjustment was 3 


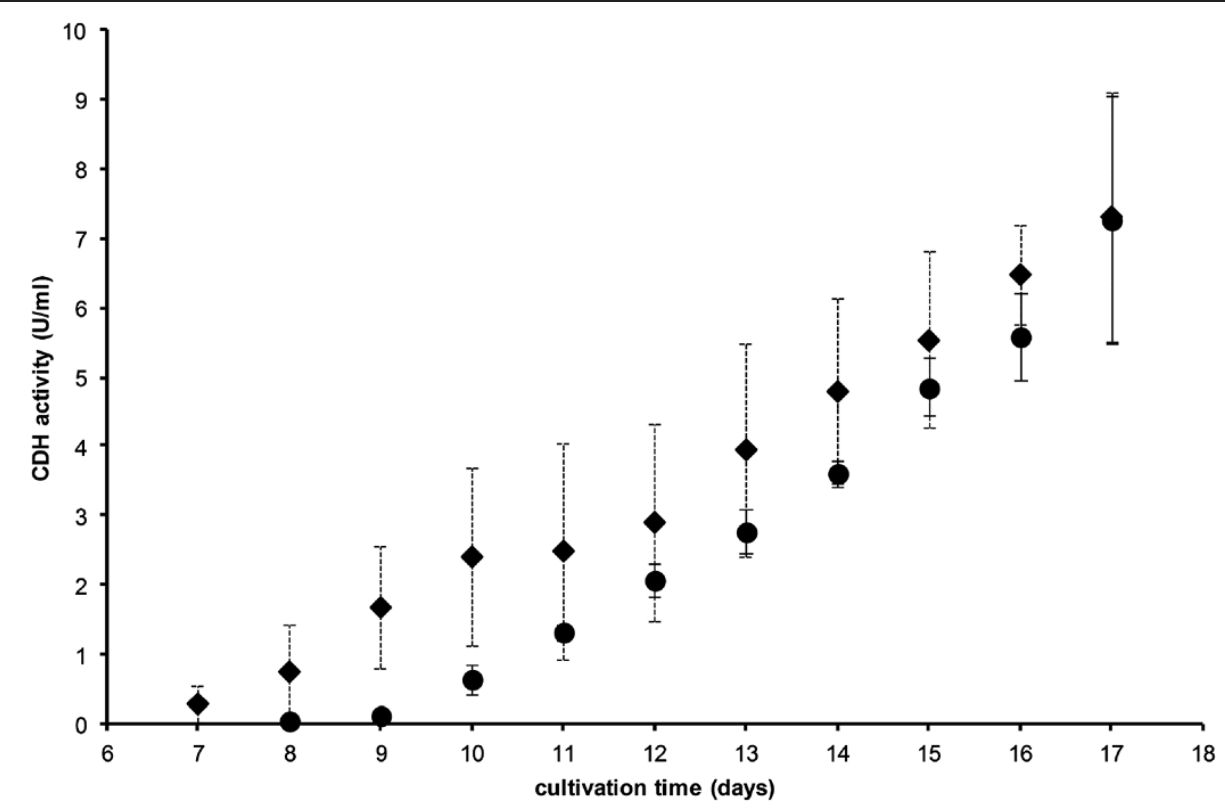

Figure 2 Influence of start pH on CDH production by S. rolfsii. pH $5.5(\bullet, n=18), \mathrm{pH} 5.0(\bullet, n=4)$.

times higher at that time. Consequently, control of $\mathrm{pH}$ is not favorable.

\section{Influence of medium composition}

Influence of medium composition was studied by omitting a particular salt in the medium proposed by Sachslehner et al. [2]. The latter was used as a reference medium. As can be seen from Figure 3, enzyme activity in the reference medium is constantly increasing from day 7 to 13 and then maintains at a nearly constant level from day 14 to 20 .

$\mathrm{KH}_{2} \mathrm{PO}_{4}$ seems to have a negative impact on enzyme production as when omitting this salt, a significantly higher enzyme concentration could be reached as can be seen clearly from the data at days 14 to 17 . Although, compared to the reference medium there seems to be a small decline in enzyme concentration with ongoing cultivation, so that at day 20 enzyme activity reached the

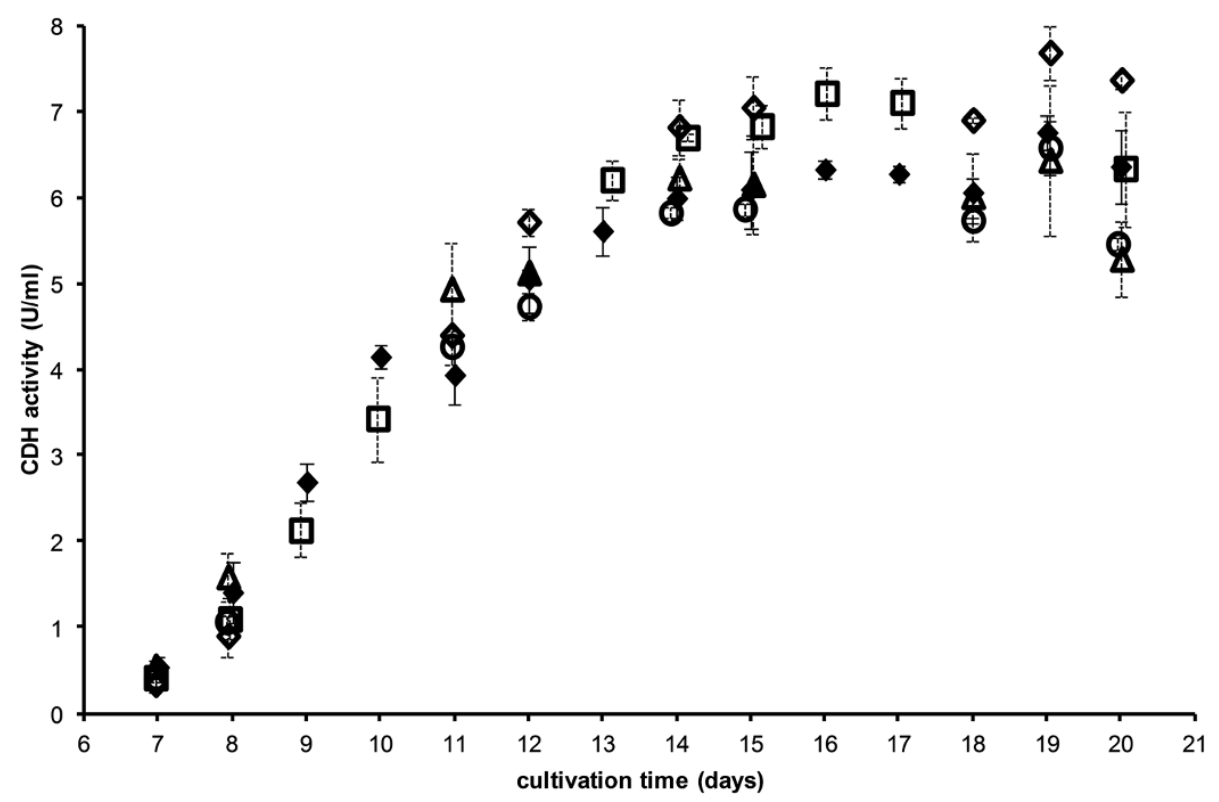

Figure $3 \mathrm{CDH}$ production by S. rolfsii. reference medium $(\bullet, n=4)$, medium lacking individual salts (without $\mathrm{NH}_{4} \mathrm{NO}_{3}(\diamond) / \mathrm{KCl}(\Delta)$ : $\mathrm{n}=3$, without $\left.\mathrm{KH}_{2} \mathrm{PO}_{4}(\square) / \mathrm{MgSO}_{4}(0): \mathrm{n}=2\right)$. 
same value $(6.3 \mathrm{U} / \mathrm{ml})$. The same can be conclude for $\mathrm{NH}_{4} \mathrm{NO}_{3}$ as there is significantly higher enzyme production from day 12 to 20 when this salt is omitted. In contrast to $\mathrm{KH}_{2} \mathrm{PO}_{4}$, enzyme concentration is enhanced until the end of the experiment resulting in about 15\% higher $\mathrm{CDH}$ concentration compared to the reference medium. On the other hand, $\mathrm{KCl}$ and $\mathrm{MgSO}_{4}$ seem to have no impact on $\mathrm{CDH}$ production as when omitting these salts no significant difference in enzyme production was observed. However, there might be a tendency that $\mathrm{CDH}$ is depleted by the fungus if cultivation would be continued as indicated by considerably lower enzyme activity values at day 20 .

A second approach was used to gain more insight in the influence of each salt. At that none or only one salt at a time was added to a basal medium containing only $\alpha$-cellulose, peptone from meat and trace element solution (amounts as in the reference medium). In all cases enzyme production by $S$. rolfsii started at the same time and reached a maximum at day 19 . There were no significant differences in $\mathrm{CDH}$ production in the first 15 days but the influence of all salts became more pronounced later (data not shown). As can be seen in Figure 4, no matter which salt was added, $\mathrm{CDH}$ production was higher compared to the reference medium. The effect was only marginal with $\mathrm{KCl}$ and $\mathrm{NH}_{4} \mathrm{NO}_{3}$ but more distinct when adding $\mathrm{KH}_{2} \mathrm{PO}_{4}$ or $\mathrm{MgSO}_{4}$. This is in contrast to the results presented above which showed no effect of $\mathrm{MgSO}_{4}$ and a negative impact of $\mathrm{KH}_{2} \mathrm{PO}_{4}$. However, with the presence of other salts, the conditions were different and therefore the impact of the individual salts could play a diverse role. As was expected, adding none of the tested salts to the basal medium also resulted in significantly higher enzyme concentration. On day $19,21 \%$ more enzyme was produced in the medium containing $\alpha$-cellulose, peptone from meat and trace element solution than in the reference medium. $\mathrm{CDH}$ concentration began to decline afterwards so one has to be careful to choose the right harvesting time. Also, when additionally omitting the trace element solution (i.e. only cultivating the fungus in $\alpha$-cellulose and meat peptone solution), a similar $\mathrm{CDH}$ production was observed (data not shown).

Using the same cultivation method (flasks containing $100 \mathrm{ml}$ medium), Sachslehner et al. [2] obtained an enzyme activity of $3.6 \mathrm{U} / \mathrm{ml}$ after 13 days of cultivation. Ludwig and Haltrich [22] achieved an enzyme concentration of $4.1 \mathrm{U} / \mathrm{ml}$ after 14 days. In 2003 they reported about $7 \mathrm{U} / \mathrm{ml}$ in the same medium after 13 days [23]. With reducing peptone from meat to $20 \mathrm{~g} / \mathrm{L}$ and adding $30 \mathrm{~g} / \mathrm{L}$ leucine instead, $11 \mathrm{U} / \mathrm{ml}$ were obtained after 13 days. This good result could not be confirmed in the present study as enzyme production using this medium composition was very low $(1.2 \pm 0.9 \mathrm{U} / \mathrm{ml}$ after 16 days $(n=4))$. The difference might be due to the usage of meat peptone from different suppliers therefore resulting in a different composition.

\section{Enzyme purification}

\section{Optimization of ion exchange chromatography}

To choose an appropriate anion exchange medium, the binding capacity of two materials was determined by

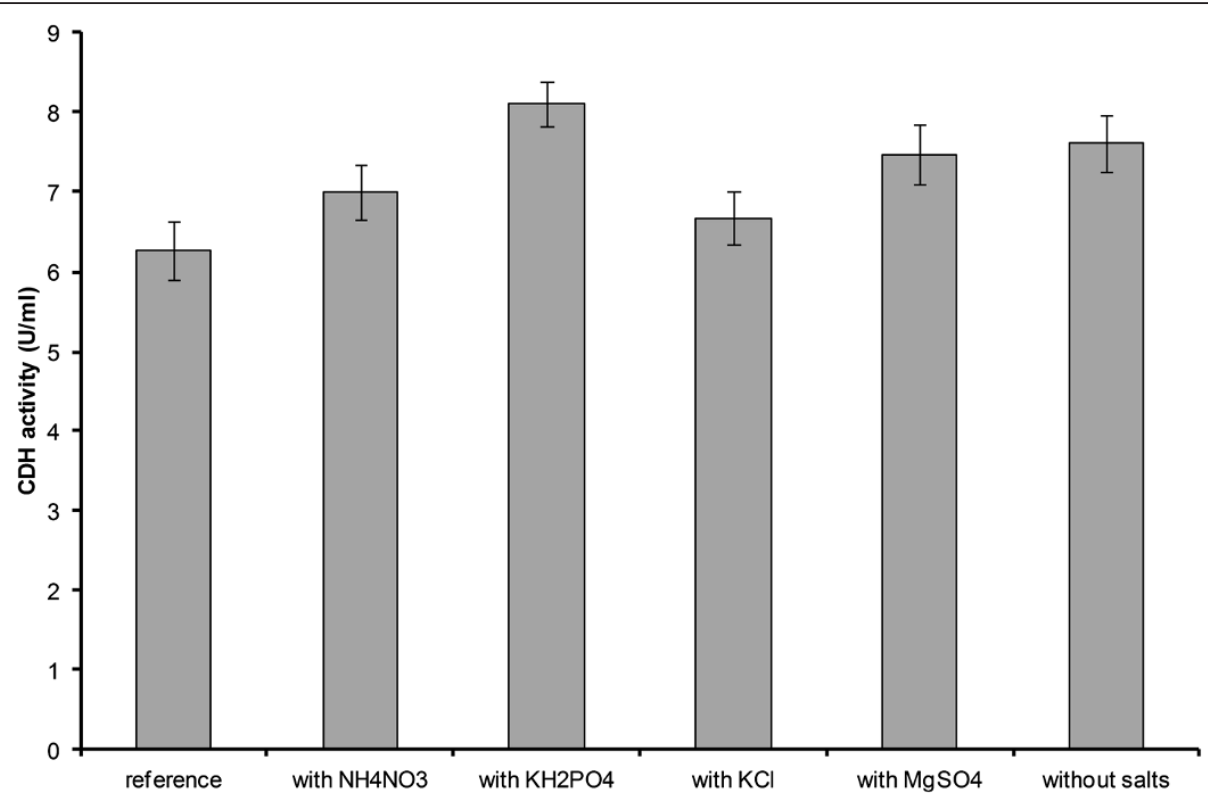

Figure $4 \mathrm{CDH}$ production by $\mathrm{S}$. rolfsii after 19 days of cultivation in different culture media. reference $n=6, N_{4} N_{3} n=3, K_{2} P_{4} n=2$, $\mathrm{KCl} n=4, \mathrm{MgSO}_{4} \mathrm{n}=5$, without salts $\mathrm{n}=5$. 


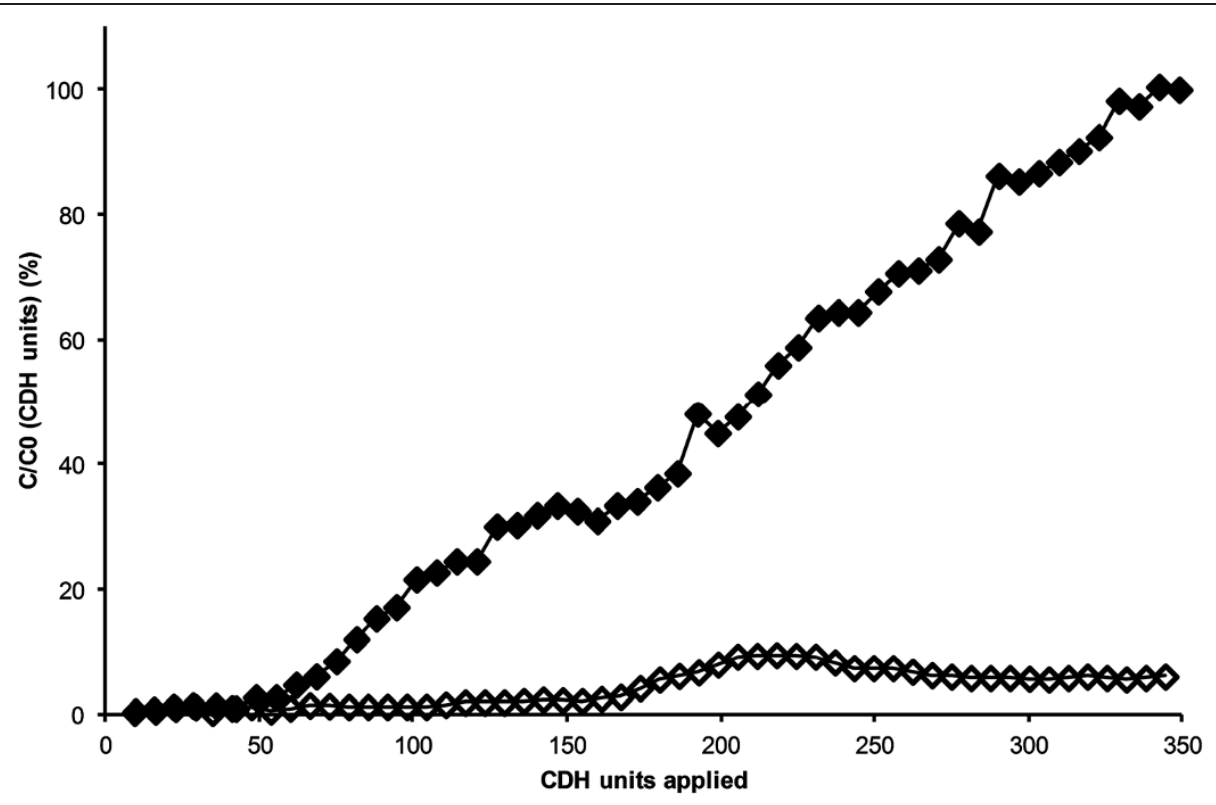

Figure 5 Breakthrough curves for $\mathrm{CDH}$ at pH 5.0. DEAE Sepharose FF ( $\bullet$ ), Q Sepharose XL ( $)$ ).

applying 350 units onto the column and determining breakthrough curves. As can be seen from Figure 5, with the weak anion exchange medium (DEAE Sepharose FF) the breakthrough was negligible until about 50 units were applied. After that, the amount of unbound enzyme increases linearly thus reaching a value of $\mathrm{c} / \mathrm{c}_{0}$ of $100 \%$ (meaning the sample leaves the column as it is, no more enzyme binds onto the column) after 350 units were applied. In contrast, with the strong anion exchanger $(\mathrm{Q}$ Sepharose XL) at the same $\mathrm{pH}$ of 5.0, the breakthrough profile always stays below $10 \%$ therefore indicating to be more suitable for $\mathrm{CDH}$ binding in general.

Hence, the $\mathrm{CDH}$ breakthrough profiles for various $\mathrm{pH}$ values were studied using Q Sepharose XL. A pH of 4.5 is very close to the isoelectric point of the enzyme (as reported to be 4.2 [24]), however the breakthrough stays below 5\% until 140 units are applied (Figure 6). After that, enzyme loss increases exponentially reaching $100 \%$ breakthrough after 215 units were applied. Even higher $\mathrm{c} / \mathrm{c}_{0}$ values were obtained meaning that not only

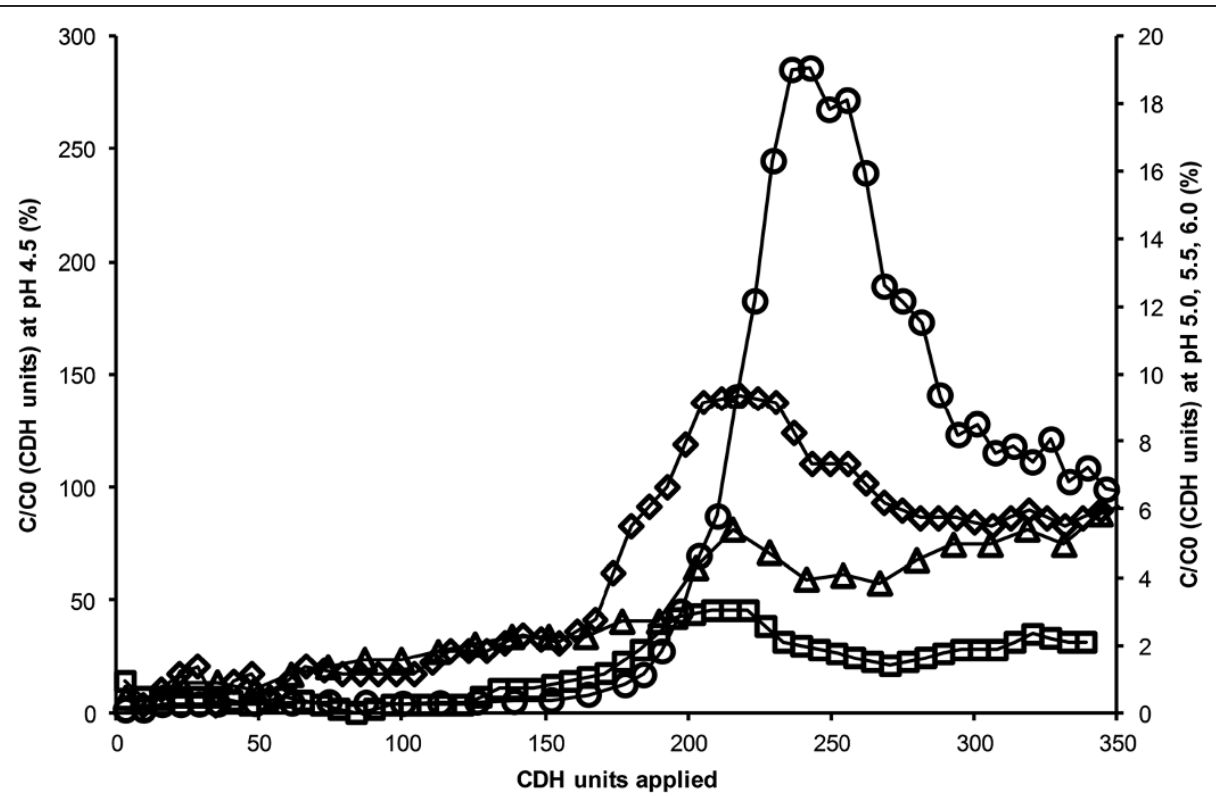

Figure 6 Breakthrough curves for CDH on Q Sepharose XL. pH $4.5(\circ)$ on the left axis, pH $5.0(\diamond), 5.5(\Delta)$ and 6.0 ( $\square$ ) on the right axis. 
no enzyme from the feed solution binds but also that most of the already bound enzyme is washed from the column. When setting the start buffer to a $\mathrm{pH}$ of 5.5 or 6.0 the maximum breakthrough is $6 \%$ and $3 \%$ respectively. Table 1 shows the calculated dynamic binding capacity (defined at 5\% breakthrough) for $\mathrm{CDH}$ for both columns at the studied $\mathrm{pH}$ values. For $\mathrm{pH} 6.0 \mathrm{dy}$ namic binding capacity could not be determined properly as breakthrough stayed below the critical value of $5 \%$. As can be seen, with the DEAE Sepharose FF column the dynamic binding capacity and therefore the amount of enzyme that should be applied to the column to keep loss at a minimum, is very low (about 60 units) compared to the dynamic binding capacity with the Q Sepharose XL column (about 180 units). As can be seen from Table 1, dynamic binding capacity is rising with increasing $\mathrm{pH}$. This can be explained by a stronger net charge of the enzyme and therefore a better binding of $\mathrm{CDH}$ to the column material. In theory, when using $\mathrm{pH}$ values closer to the isoelectric point, the binding of other proteins should be less. However, as can be seen from Table 1, this effect is marginal as the specific enzyme activity determined in the elution peak is only a little higher at pH 4.5 (only 160 units were applied as otherwise all enzyme would be lost during sample application and wash) than at the other $\mathrm{pH}$ values studied. But, more other proteins compared to $\mathrm{CDH}$ bind on the DEAE Sepharose FF column as indicated by the low specific activity of $1 \mathrm{U} / \mathrm{mg}$ which is another reason for not choosing this material for purification. Nevertheless, Baminger et al. [24] used a DEAE Sepharose FF column as a capture step with a good purification effect. However, this result could not be obtained during this study (purification fold about 2.3 when applying 50 units).

Next, ionic strength of the starting buffer was varied from $20 \mathrm{mM}$ to $200 \mathrm{mM}$ sodium acetate ( $\mathrm{pH} \mathrm{4.5)}$ to determine the maximum possible molarity where $\mathrm{CDH}$ still binds but most of the other proteins do not. About 130 units $\mathrm{CDH}$ were applied to stay below the previously determined dynamic binding capacity. Three samples were taken from each run and analyzed for $\mathrm{CDH}$ activity and protein content during sample application, washing, and

Table 1 dynamic binding capacity determined at $5 \%$ breakthrough and specific enzyme activity in the elute

\begin{tabular}{llll}
\hline Column & $\begin{array}{l}\text { pH } \\
\text { value }\end{array}$ & $\begin{array}{l}\text { Dynamic binding } \\
\text { capacity (Units) }\end{array}$ & $\begin{array}{l}\text { Specific } \\
\text { activity (U/mg) }\end{array}$ \\
\hline Q Sepharose XL & 4.5 & 140 & 1.6 \\
Q Sepharose XL & 5.0 & 180 & 1.5 \\
Q Sepharose XL & 5.5 & 210 & 1.5 \\
Q Sepharose XL & 6.0 & $>350$ & 1.5 \\
DEAE Sepharose FF & 5.0 & 62 & 1.0 \\
\hline
\end{tabular}

elution. As expected, the amount of total bound protein is decreasing with increasing ionic strength (Figure 7). Concurrent, about $95 \%$ of the applied $\mathrm{CDH}$ is bound to the column at buffer concentrations from 20 to $50 \mathrm{mM}$. As a consequence, the purification factor is rising. At a sodium acetate concentration of $100 \mathrm{mM}$ only $87.5 \%$ of the enzyme is bound. However, the purification is better because simultaneously to some enzyme loss, a comparatively larger amount of other proteins is also not able to bind. Indeed, when the start buffer has a concentration of $200 \mathrm{mM}$, nearly the entire enzyme is eluted during sample application and washing therefore resulting in a loss of $95 \%$. A loss of about $12.5 \%$ as detected at $100 \mathrm{mM}$ was decided to be acceptable. Therefore this ionic strength was used in further studies.

Elution conditions were optimized by first using a linear gradient from 0 to $0.4 \mathrm{M} \mathrm{NaCl}$ in $100 \mathrm{mM}$ sodium acetate buffer at various $\mathrm{pH}$ values $(4.5,6.0$ and 8.0) in 20 column volumes $(\mathrm{CV})$. Two not well resolved peaks were obtained when eluting with the same $\mathrm{pH}$ (4.5) as was used during sample application and wash. $\mathrm{CDH}$ eluted mainly in the first peak but had a distinct tailing into the second peak (Figure 8). When setting the $\mathrm{pH}$ to 6.0 , peak separation was better because a number of other proteins were more strongly retained onto the column compared to $\mathrm{CDH}$. Thus, purification factor was rising from 3.3 to 4.7. With further increasing of the $\mathrm{pH}$ to $8.0 \mathrm{CDH}$ was also bound more strongly to the column material, i.e. some other proteins eluted first, followed by $\mathrm{CDH}$ and more proteins from this complex mixture. The purification factor remained the same (4.7). A $\mathrm{pH}$ value of 6.0 was considered to be most suited for elution.

\section{Optimization of hydrophobic interaction chromatography}

To choose an appropriate hydrophobic interaction medium for the second purification step, the binding properties of several materials was determined by applying 30 units onto the columns and determining breakthrough curves. From the various columns tested, only Phenyl HP was suited for $\mathrm{CDH}$ purification as with the other columns $\mathrm{CDH}$ binding was weak indicated by high $\mathrm{c} / \mathrm{c}_{0}$ values right from the beginning of sample application (data not shown). Using Butyl-S FF, Octyl FF and Phenyl FF low sub the entire enzyme was lost during sample application and washing. With the Butyl-FF column some of the enzyme was bound but loss was still high with $70 \%$. Therefore all further experiments were carried out with a Phenyl HP column.

Next, ammonium sulfate concentration (0.5 M, 0.9 $\mathrm{M}$, and $1.1 \mathrm{M}$ ) in the starting buffer was varied. Also, the effect of adding $\mathrm{NaCl}(0.2 \mathrm{M}, 2.1 \mathrm{M})$ was studied. An ammonium sulfate concentration of $0.5 \mathrm{M}$ is too low which could also be seen from the breakthrough 


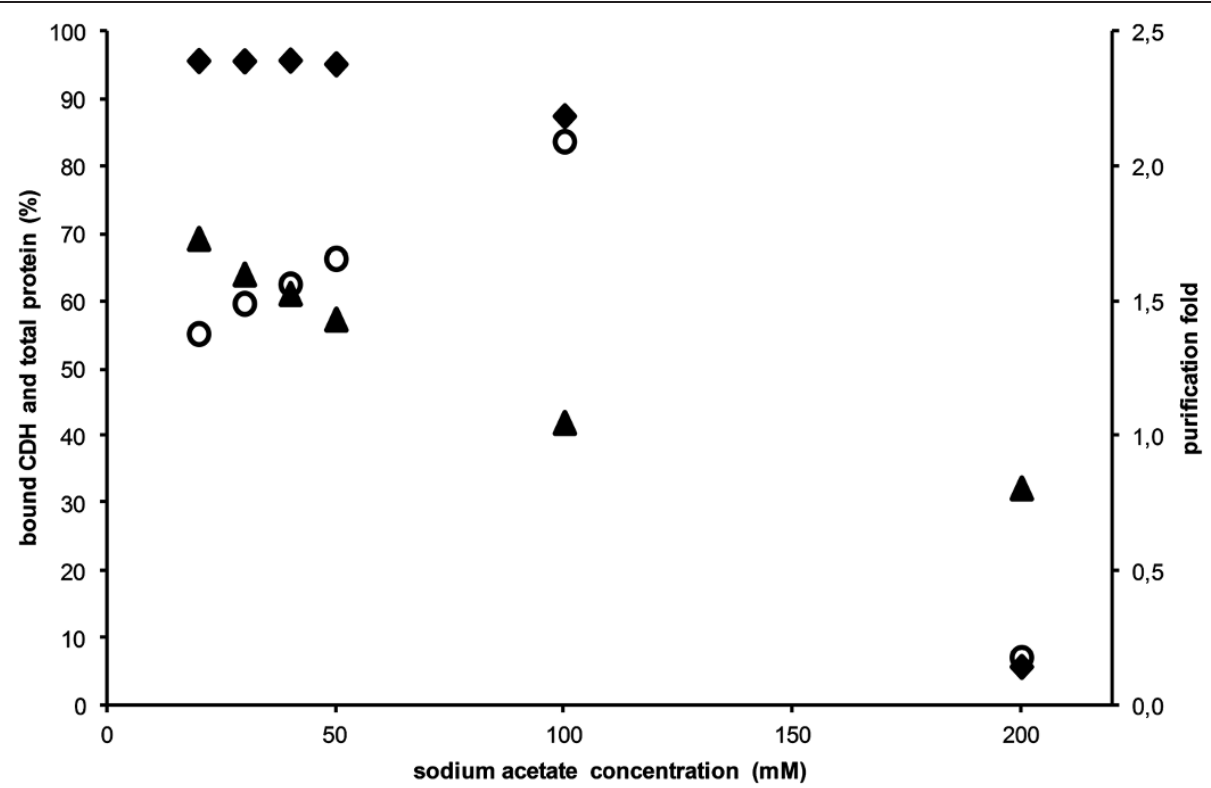

Figure $7 \mathrm{CDH}$ purification as a function of buffer concentration on Q Sepharose $\mathbf{X L}$. amount of bound CDH units ( $\downarrow$, left axis), total protein $(\boldsymbol{\Lambda}$, left axis), purification factor (o, right axis).

profile as most of the enzyme was not bound therefore resulting in a high loss of nearly $70 \%$. Raising the concentration of $\left(\mathrm{NH}_{4}\right)_{2} \mathrm{SO}_{4}$ to $0.9 \mathrm{M}$ (as was used by Baminger et al. [24] on a Phenyl Resource column) was also not sufficient as most of the target enzyme was eluting during the washing step (loss about $60 \%$ ). Thus, 1.1 $\mathrm{M}$ ammonium sulfate was used as loss was only a third (19\%). When adding $0.2 \mathrm{M} \mathrm{NaCl}$ to the starting buffer, enzyme loss could be minimized (about 10\%). A further increase of $\mathrm{NaCl}$ to $2.1 \mathrm{M}$ resulted in an enhanced binding of other proteins which in turn resulted in a worse separation during elution. To gain a certain specific activity more enzyme loss would have to be taken into account.

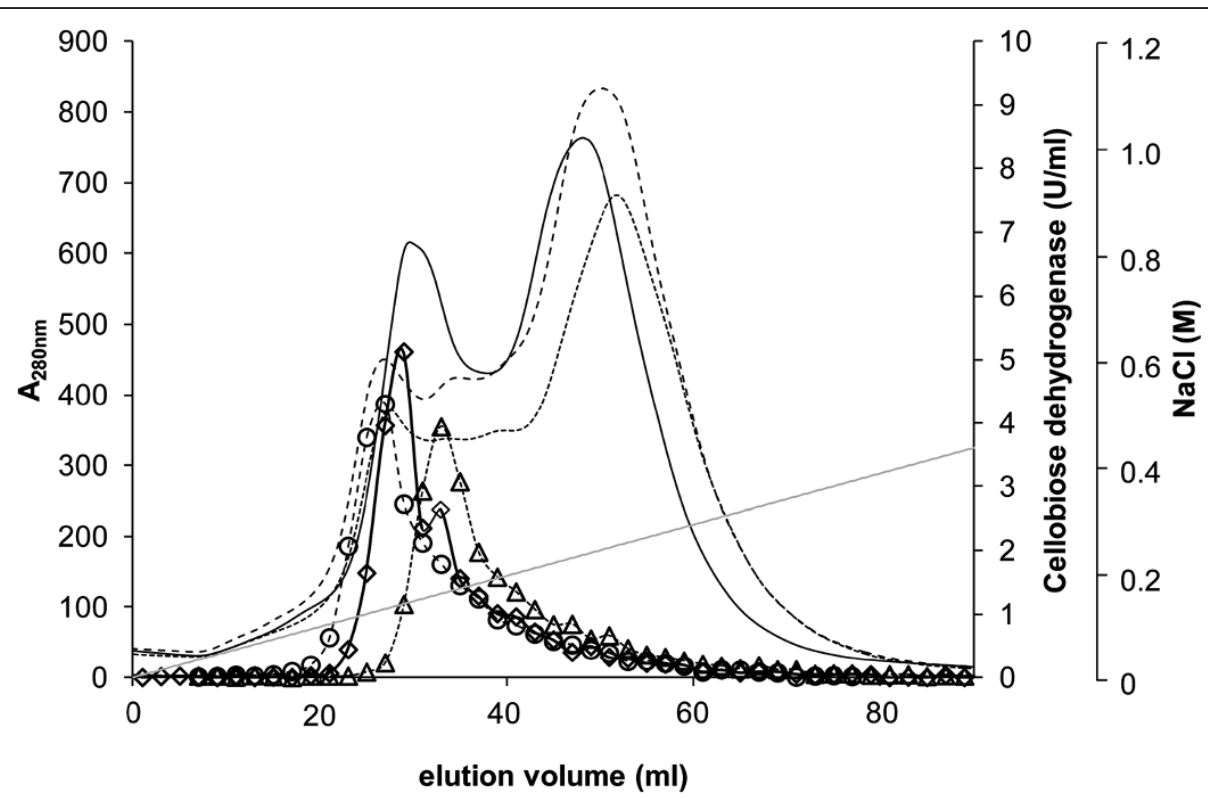

Figure 8 Elution profiles of $\mathrm{CDH}$ on $\mathrm{Q}$ Sepharose $\mathrm{XL}$ at various pH values. $\mathrm{pH} 4.5\left(\mathrm{CDH} \diamond, \mathrm{A}_{280 \mathrm{~nm}}\right.$ straight line), $\mathrm{pH} 6.0$ (CDH $0, \mathrm{~A}_{280 \mathrm{~nm}}$ dashed line), $\mathrm{pH} 8.0$ ( $\mathrm{CDH} \Delta, \mathrm{A}_{280 \mathrm{~nm}}$ fine dashed line), elution buffer was $1 \mathrm{M} \mathrm{NaCl}$ in $100 \mathrm{mM}$ sodium acetate, gradient from 0 to $0.4 \mathrm{M} \mathrm{NaCl}$ in $20 \mathrm{CV}$. 
Table 2 Purification of cellobiose dehydrogenase from Sclerotium rolfsii

\begin{tabular}{llllll}
\hline $\begin{array}{l}\text { Purification } \\
\text { step }\end{array}$ & $\begin{array}{l}\text { CDH } \\
\text { activity } \\
\text { (Units) }\end{array}$ & $\begin{array}{l}\text { Total } \\
\text { protein } \\
\text { (mg) }\end{array}$ & $\begin{array}{l}\text { Specific } \\
\text { activity } \\
\text { (U/mg) }\end{array}$ & $\begin{array}{l}\text { Purification } \\
\text { fold }\end{array}$ & $\begin{array}{l}\text { Yield } \\
\text { (\%) }\end{array}$ \\
\hline Crude extract & 1173 & 1112 & 1.1 & 1.0 & 100 \\
IEX (Q Sepharose XL) & 974 & 456 & 2.1 & 2.0 & 83 \\
$\begin{array}{l}\left(\mathrm{NH}_{4}\right)_{2} \mathrm{SO}_{4} \\
\text { precipitation }\end{array}$ & 750 & 398 & 1.9 & 1.8 & 64 \\
$\mathrm{HIC}$ (Phenyl HP) & 661 & 56 & 11.9 & 11.3 & 56 \\
\hline
\end{tabular}

\section{Tandem purification protocol}

A method was established that combined IEX and HIC to purify $\mathrm{CDH}$ further since enzyme purification using either IEX or HIC was not sufficient. As higher enzyme loading is possible for IEX on Q Sepharose XL, a pH of 5.0 was chosen for the starting buffer $(100 \mathrm{mM}$ sodium acetate). Sample solution was diluted 2 -fold with starting buffer (resulting in about $20 \mathrm{U} / \mathrm{ml}$ ) and applied to the column at a speed of $1 \mathrm{ml} / \mathrm{min}$. All further steps were carried out at $5 \mathrm{ml} / \mathrm{min}$. The optimized elution profile includes a linear increase from 0 to $0.15 \mathrm{M} \mathrm{NaCl}$ in 8 $\mathrm{CV}$, a hold at $0.15 \mathrm{M} \mathrm{NaCl}$ for $4 \mathrm{CV}$ and a stepwise increase to $1 \mathrm{M} \mathrm{NaCl}$ (hold $7 \mathrm{CV}$ ). After an ammonium
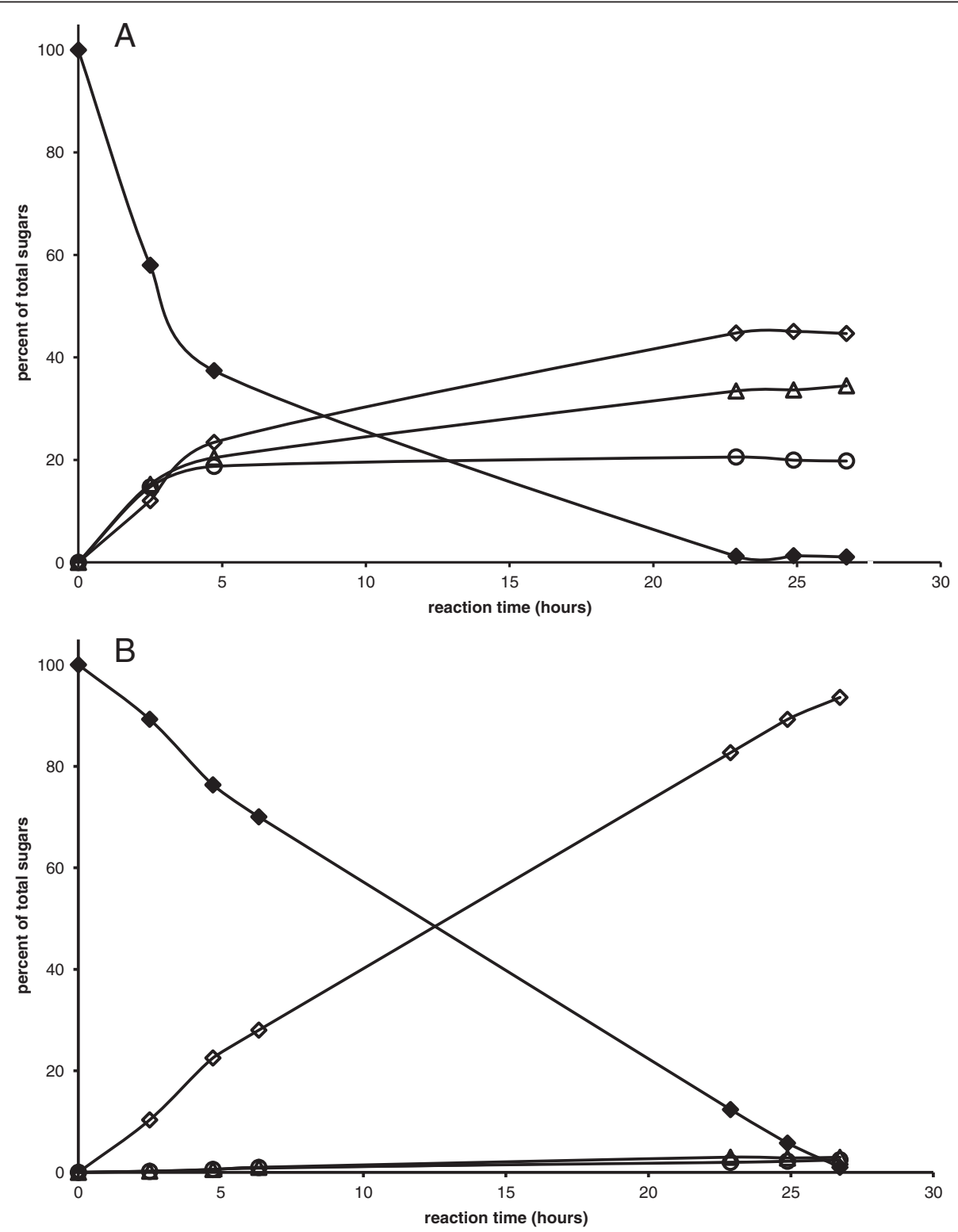

Figure 9 Oxidation of lactose using crude enzyme extract (A) and purified enzyme (B). lactobionic acid ( ()$)$, glucose (o), galactose $(\Delta)$, lactose $(\bullet)$. 
sulfate precipitation the supernatant was applied to HIC on a Phenyl HP column (volume: $5 \mathrm{ml}$ ). The equilibration buffer contained 1.1 M ammonium sulfate and 0.2 $\mathrm{M} \mathrm{NaCl}$ in $100 \mathrm{mM}$ sodium acetate buffer $\mathrm{pH}$ 5.0. Flow rate was set to $5 \mathrm{ml} / \mathrm{min}$ for the entire procedure. Elution was performed by increasing buffer B $(50 \mathrm{mM}$ sodium acetate $\mathrm{pH} 5.0$ ) from 0 to $100 \%$ in $8 \mathrm{CV}$. Table 2 shows the overall purification protocol.

However, the obtained enzyme solution after hydrophobic interaction chromatography still contains some other proteins than $\mathrm{CDH}$ as could be detected by SDSPAGE, i.e. the final enzyme solution is not $100 \%$ pure. To evaluate if the other proteins have a negative effect on the oxidation of lactose to lactobionic acid (i.e. hydrolysis into glucose and galactose catalyzed by enzymes like $\alpha$-galactosidase or $\beta$-glucosidase which are also produced by the fungus [2]), the enzyme solution was used in a $4.8 \%$ lactose solution. For comparison, the crude enzyme extract was used in another experiment.

As can be seen clearly from Figure 9A, using unpurified extract leads to high amounts of glucose and galactose caused by $\alpha$-galactosidases or $\beta$-glucosidases as described before. Thus, yield of lactobionic acid was only $45 \%$. Using partial purified enzyme as described in this paper (Figure 9B), only minor amounts of monosaccharides (3\% galactose, $2.5 \%$ glucose) could be detected and therefore the obtained purity is sufficient for the intended use of $\mathrm{CDH}$. In 27 hours it was possible to obtain a lactobionic acid yield of $94 \%$ which is more than twice as much compared to the crude enzyme solution. However, one might also consider using the unpurified extract depending on the exact application, thus saving costs for enzyme purification. Lactobionic acid might further be tested regarding its potential prebiotic effect [11]. The tolerance in humans is already shown [25]. It can further be used as a calcium salt in food applications as a stabilizer. It is also commonly used in the Wisconsin transplantation solution as an organ preservative [26].

\section{Preservation of purified CDH}

Experiments for evaluating two possibilities (freezing and freeze-drying) to preserve $\mathrm{CDH}$ were carried out at high enzyme concentration $(11,000 \mathrm{U} / \mathrm{L})$ as residual activity is generally higher at higher enzyme concentration $[27,28]$. Sugars are known to be effective in stabilizing enzymes during freeze-drying therefore acting as lyoprotectants $[27,29,30]$ but no studies on $\mathrm{CDH}$ recovery during freeze-drying are known so far.

Figure 10 shows the residual $\mathrm{CDH}$ activity compared to the sample before freezing or freeze-drying. As can be seen, without using a lyoprotectant most of the $\mathrm{CDH}$ is inactivated during freeze-drying leaving a residual activity of only $23 \%$. Glycerol could stabilize the enzyme to some extent while mannitol could not. In general, it was more effective using sugars as stabilizing agents than sugar alcohols. With glucose and lactulose no loss in activity was observed. With the other disaccharides lactose, cellobiose, and maltose over $80 \%$ of $\mathrm{CDH}$ could be retained while galactose and raffinose are considered to be less effective. However, residual activity was a lot higher compared to the two sugar alcohols tested.

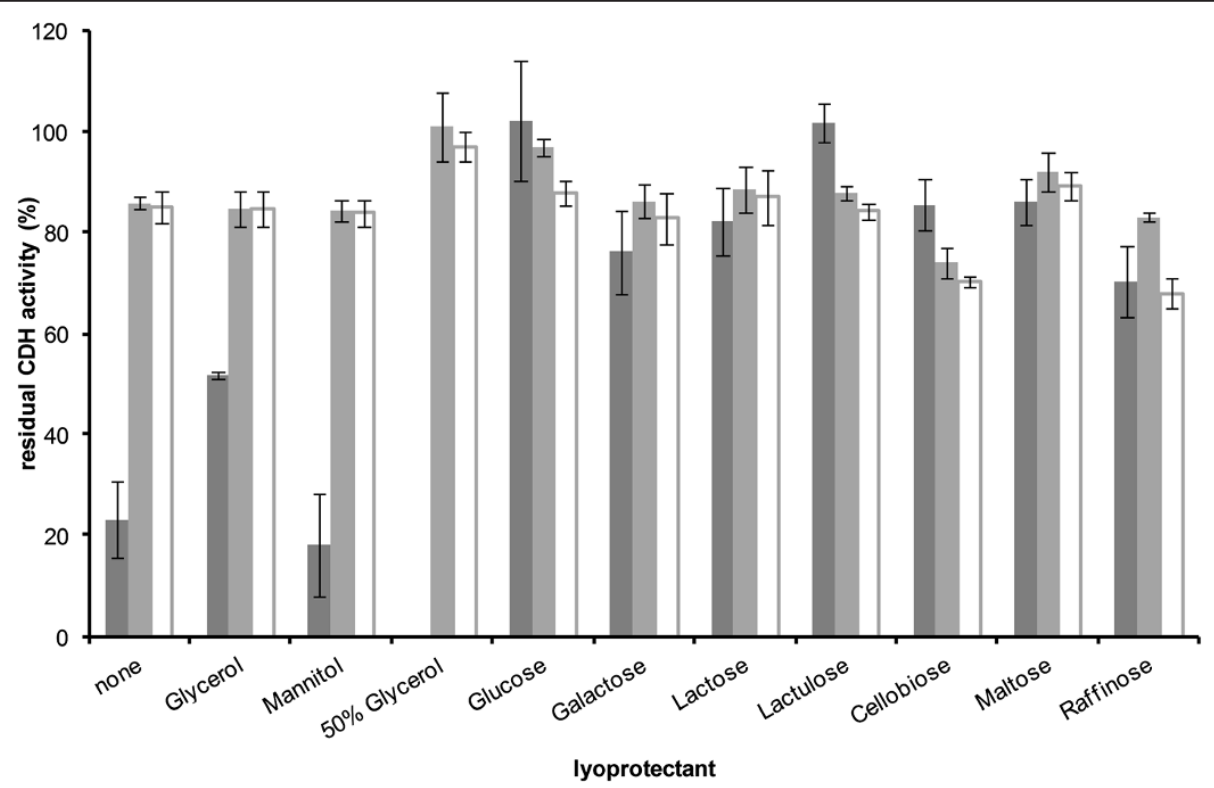

Figure 10 Preservation of $\mathrm{CDH}$. The figure shows the residual $\mathrm{CDH}$ activity after lyophilisation (dark grey) or freezing after 60 hours (light grey) or 160 hours (white) in the absence (none) or presence of different lyoprotectants (10 $\mu \mathrm{mol} / \mathrm{unit}$ ), $\mathrm{n}=3$. 
In another series, storage of the enzyme at $-20^{\circ} \mathrm{C}$ was evaluated. In general, a solution of $50 \%(\mathrm{w} / \mathrm{v})$ glycerol is often used when trying to make enzymes storable. Therefore, as expected, using high glycerol concentrations gave a residual activity of $100 \%$ after 60 hours of storage. However, after 160 hours a small decline is observed. Also, glucose seems to be very effective although enzyme stability might not be satisfying as indicated by the relatively high drop in $\mathrm{CDH}$ activity after 160 hours compared to stable activity values when using lactose, glycerol, mannitol or no lyoprotectant. On the other hand, cellobiose clearly has a negative effect in enzyme stability during freezing as residual activity values are below the ones when using no additives. Raffinose, similar to glucose, is stabilizing the enzyme at the beginning of the process but with prolonged storage it seems to be less effective and therefore being not suitable.

Generally, freezing at $-20^{\circ} \mathrm{C}$ effects enzyme activity to a much lesser extent than freeze-drying as can be seen from the data when using no further agents. Although it is shown that with adding glucose or lactulose no activity is lost, the process of freeze-drying is obviously more cost and time consuming than simply freezing the solution at $-20^{\circ} \mathrm{C}$. Additionally, when adding the right amount of glycerol (no effect was observed when using only $10 \mu \mathrm{mol}$ per unit) it is also possible to retain all of the enzyme activity. It has to be noted that the experiments carried out during this study are only considered to be preliminary. More research is necessary in studying enzyme behavior during storage, for example determining the half-life time.

\section{Conclusions}

To produce cellobiose dehydrogenase from Sclerotium rolfsii, it was possible to simplify a rather complex cultivation medium to a basic medium consisting only of $\alpha$-cellulose, peptone from meat, and trace elements. Additionally, enzyme production was increased by $21 \%$. Purification of the enzyme was studied systematically resulting in a yield of $56 \%$. Although other proteins were detected in the resulting enzyme solution, its purity was considered to be sufficient for oxidizing lactose to lactobionic acid. With freeze-drying of $\mathrm{CDH}$, glucose and lactulose could be identified to be good lyoprotectants. However, freezing at $-20^{\circ} \mathrm{C}$ is preferred for storage as this method being much simpler and residual activity being $100 \%$ when using $50 \%(\mathrm{w} / \mathrm{v})$ glycerol.

\section{Competing interests}

The authors declare that they have no competing interests.

\section{Authors' contributions}

CF designed the study, carried out the experimental work and drafted the manuscript. AK participated in the design of the study and commented on the manuscript. TK conceived the study, participated in its design and commented on the manuscript. All authors read and approved the final manuscript.

\section{Acknowledgements}

The authors would like to thank Julia Streithoff for her support during the experimental work.

Received: 2 April 2014 Accepted: 30 October 2014

Published online: 19 November 2014

\section{References}

1. Henriksson G, Johansson G, Pettersson G: A critical review of cellobiose dehydrogenases. J Biotechnol 2000, 78(2):93-113.

2. Sachslehner A, Haltrich D, Nidetzky B, Kulbe KD: Production of Hemicellulose- and Cellulose-Degrading Enzymes by Various Strains of Sclerotium Rolfsii. Appl Biochem Biotechnol 1997, 63-65(1-3):189-201.

3. Cameron MD, Aust SD: Cellobiose dehydrogenase - an extracellular fungal flavocytochrome. Enzyme Microb Technol 2001, 28(2-3):129-138.

4. Kruså M, Lennholm H, Henriksson G: Pre-treatment of cellulose by cellobiose dehydrogenase increases the degradation rate by hydrolytic cellulases. Cellul Chem Technol 2007, 41(2-3):105-111.

5. Karapetyan KN, Fedorova TV, Vasil'chenko LG, Ludwig R, Haltrich D, Rabinovich ML: Properties of neutral cellobiose dehydrogenase from the ascomycete Chaetomium sp. INBI 2-26(-) and comparison with basidiomycetous cellobiose dehydrogenases. J Biotechnol 2006, 121(1):34-48.

6. Subramaniam SS, Nagalla SR, Renganathan V: Cloning and Characterization of a Thermostable Cellobiose Dehydrogenase from Sporotrichum thermophile. Arch Biochem Biophys 1999, 365(2):223-230.

7. Fang J, Liu W, Gao PJ: Cellobiose Dehydrogenase from Schizophyllum commune: Purification and Study of Some Catalytic, Inactivation, and Cellulose-Binding Properties. Arch Biochem Biophys 1998, 353(1):37-46.

8. Saha T, Ghosh D, Mukherjee S, Bose S, Mukherjee M: Cellobiose dehydrogenase production by the mycelial culture of the mushroom Termitomyces clypeatus. Process Biochem 2008, 43(6):634-641.

9. Henriksson G, Sild V, Szabó IJ, Pettersson G, Johansson G: Substrate specificity of cellobiose dehydrogenase from Phanerochaete chrysosporium. Biochim Biophys Acta Protein Struct Mol Enzymol 1998, 1383(1):48-54

10. Ayers AR, Ayers SB, Eriksson KE: Cellobiose Oxidase, Purification and Partial Characterization of a Hemoprotein from Sporotrichum pulverulentum. Eur J Biochem 1978, 90(1):171-181.

11. Schaafsma G: Lactose and lactose derivatives as bioactive ingredients in human nutrition. Int Dairy J 2008, 18(5):458-465

12. Tasca F, Zafar MN, Harreither W, Nöll G, Ludwig R, Gorton L: A third generation glucose biosensor based on cellobiose dehydrogenase from Corynascus thermophilus and single-walled carbon nanotubes. Analyst 2011, 136(10):2033-2036.

13. Zafar MN, Safina G, Ludwig R, Gorton L: Characteristics of third-generation glucose biosensors based on Corynascus thermophilus cellobiose dehydrogenase immobilized on commercially available screen-printed electrodes working under physiological conditions. Anal Biochem 2012, 425(1):36-42.

14. Yakovleva M, Buzas O, Matsumura H, Samejima M, Igarashi K, Larsson PO, Gorton L, Danielsson B: A novel combined thermometric and amperometric biosensor for lactose determination based on immobilised cellobiose dehydrogenase. Biosensors Bioelectron 2012, 31(1):251-256.

15. Tasca F, Ludwig R, Gorton L, Antiochia R: Determination of lactose by a novel third generation biosensor based on a cellobiose dehydrogenase and aryl diazonium modified single wall carbon nanotubes electrode. Sensors Actuators B Chem 2013, 177:64-69.

16. Knöös P, Schulz C, Piculell L, Ludwig R, Gorton L, Wahlgren M: Quantifying the release of lactose from polymer matrix tablets with an amperometric biosensor utilizing cellobiose dehydrogenase. Int J Pharm 2014, 468(1-2):121-132.

17. Enayatzamir K, Tabandeh F, Yakhchali B, Alikhani HA, Rodríguez Couto S: Assessment of the joint effect of laccase and cellobiose dehydrogenase on the decolouration of different synthetic dyes. J Hazard Mater 2009, 169(1-3):176-181.

18. Tilli S, Ciullini I, Scozzafava A, Briganti F: Differential decolorization of textile dyes in mixtures and the joint effect of laccase and cellobiose dehydrogenase activities present in extracellular extracts from Funalia trogii. Enzyme Microb Technol 2011, 49(5):465-471. 
19. Flitsch A, Prasetyo EN, Sygmund C, Ludwig R, Nyanhongo GS, Guebitz GM: Cellulose oxidation and bleaching processes based on recombinant Myriococcum thermophilum cellobiose dehydrogenase. Enzyme Microb Technol 2013, 52(1):60-67.

20. Baminger U, Nidetzky B, Kulbe KD, Haltrich D: A simple assay for measuring cellobiose dehydrogenase activity in the presence of laccase. J Microbiol Methods 1999, 35(3):253-259.

21. Bradford MM: A rapid and sensitive method for the quantitation of microgram quantities of protein utilizing the principle of protein dye binding. Anal Biochem 1976, 72(1-2):248-254.

22. Ludwig R, Haltrich D: Cellobiose dehydrogenase production by Sclerotium species pathogenic to plants. Lett Appl Microbiol 2002, 35(3):261-266.

23. Ludwig R, Haltrich D: Optimisation of cellobiose dehydrogenase production by the fungus Sclerotium (Athelia) rolfsii. Appl Microbiol Biotechnol 2003, 61(1):32-39.

24. Baminger U, Subramaniam SS, Renganathan V, Haltrich D: Purification and Characterization of Cellobiose Dehydrogenase from the Plant Pathogen Sclerotium (Athelia) rolfsii. Appl Environ Microbiol 2001, 67(4):1766-1774.

25. Van Dokkum W, Wezendonk LJW, van Aken-Schneider P, Kistemaker C: The tolerance of lactobionic acid in man. 1994. TNO Report, V94.115, TNO Nutrition and Food Research, Zeist, The Netherlands.

26. Playne MJ, Crittenden RG: Galacto-oligosaccharides and Other Products Derived from Lactose. In Advanced Dairy Chemistry, Volume 3: Lactose, Water, Salts and Minor Constituents. Heidelberg: Springer- Verlag; 2009:121-201.

27. Tanaka K, Takeda T, Miyajima K: Cryoprotective Effect of Saccharides on Denaturation of Catalase by Freeze-Drying. Chem Pharm Bull (Tokyo) 1991, 39(5):1091-1094

28. Capolongo A, Barresi AA, Rovero G: Freeze-drying of lignin peroxidase: Influence of lyoprotectants on enzyme activity and stability. J Chem Technol Biotechnol 2003, 78(1):56-63.

29. D'Andrea G, Salucci ML, Avigliano L: Effect of Lyoprotectants on Ascorbate Oxidase Activity after Freeze-Drying and Storage. Process Biochem 1995, 31(2):173-178.

30. Corveleyn S, Remon JP: Maltodextrins as Lyoprotectants in the Lyophilization of a Model Protein. LDH Pharm Res 1996, 13(1):146-150. and lyophilisation of cellobiose dehydrogenase by Sclerotium rolfsii. BMC Biotechnology 2014 14:97.

\section{Submit your next manuscript to BioMed Central and take full advantage of:}

- Convenient online submission

- Thorough peer review

- No space constraints or color figure charges

- Immediate publication on acceptance

- Inclusion in PubMed, CAS, Scopus and Google Scholar

- Research which is freely available for redistribution 